\title{
Variations in the Wave Climate and Sediment Transport Due to Climate Change along the Coast of Vietnam
}

\author{
Ali Dastgheib ${ }^{1, *}$, Johan Reyns ${ }^{1,2}$, Supot Thammasittirong ${ }^{3}$, Sutat Weesakul ${ }^{3,4}$, \\ Marcus Thatcher ${ }^{5}$ and Roshanka Ranasinghe ${ }^{1,2,6}$ \\ 1 UNESCO-IHE, Delft 2611 AH, The Netherlands; j.reyns@unesco-ihe.org (J.R.); \\ r.ranasinghe@unesco-ihe.org (R.R.) \\ 2 Deltares, Delft $2629 \mathrm{HV}$, The Netherlands \\ 3 Asian Institute of Technology, Bangkok 12120, Thailand; supote.th@gmail.com (S.T.); sutat@ait.ac.th (S.W.) \\ 4 Hydro and Agro Informatics Institute, Bangkok 10400, Thailand \\ 5 CSIRO, Aspendale Vic 3195, Australia; marcus.thatcher@csiro.au \\ 6 Water Engineering and Management, Faculty of Engineering Technology, University of Twente, \\ Enschede 7522 NB, The Netherlands \\ * Correspondence: a.dastgheib@unesco-ihe.com; Tel.: +31-15-2151845
}

Academic Editors: Harshinie Karunarathna and Jenifer Brown

Received: 11 October 2016; Accepted: 8 December 2016; Published: 15 December 2016

\begin{abstract}
This study quantifies the climate change (CC)-driven variations in wave characteristics and the resulting variations in potential longshore sediment transport rate along the $\sim 2000 \mathrm{~km}$ mainland coast of Vietnam. Wind fields derived from global circulation models (GCM) for current and future (2041-2060 and 2081-2100) climate conditions are used to force a numerical wave model (MIKE21 SW) to derive the deep water wave climate. The offshore wave climate is translated to nearshore wave conditions using another numerical model (Simulating WAves Nearshore-SWAN) and finally, a sediment transport model (GENEralized model for Simulating Shoreline Change-GENESIS) is used to estimate potential sediment transport for current and future climate conditions. Results indicate that CC effects are substantially different in the northern, central and southern parts of the coast of Vietnam. The 2081-2100 mean significant wave height along the northern coast is estimated to be up to $8 \mathrm{~cm}$ lower (relative to 1981-2000), while projections for central and southern coasts of Vietnam indicate slightly higher (increases of up to $5 \mathrm{~cm}$ and $7 \mathrm{~cm}$ respectively). Wave direction along the northern coast of Vietnam is projected to shift by up to $4^{\circ}$ towards the south (clockwise) by 2081-2100 (relative to 1981-2000), up to $6^{\circ}$ clockwise along the central coast and by up to $8^{\circ}$ anti-clockwise (to the north) along the southern coast. The projected potential longshore sediment transport rates show very substantial and spatially variable future changes in net transport rates along the coast of Vietnam, with increases of up to 0.5 million $\mathrm{m}^{3}$ /year at some locations (by 2081-2100 relative to 1981-2000), implying major changes in future coastline position and/or orientation. The vicinity of the highly developed city of Da Nang is likely to be particularly subject to coastline changes, with potentially an additional $875,000 \mathrm{~m}^{3}$ of sand being transported away from the area per year by the turn of the 21st century.
\end{abstract}

Keywords: climate change; dynamic downscaling; wave modelling; sediment transport; Vietnam coast

\section{Introduction}

Vietnam has been identified by the International Panel on Climate Change [1,2] as one of the countries that may be most affected by climate change (CC). In particular, the Mekong and the Red 
River deltas, featuring extremely high population densities in areas just slightly above present day mean sea level, are severely threatened by CC effects. About 18 million people, almost a quarter of the total population, live in the coastal districts lining the $\sim 2000 \mathrm{~km}$ mainland coastline of Vietnam. Early impacts of CC in the coastal zone are already threatening people's livelihoods as well as the ecological system [3].

Changes in regional wave climate and sediment transport rates, in response to climate change-driven variations of atmospheric circulation, are of particular relevance for coastal zone management and planning. Changes in alongshore gradients in longshore sediment transport (even small gradients) could result in chronic impacts such as coastline recession [4-8], inlet migration and/or intermittent closure [8-10] and ebb/flood delta depletion/accretion [1,11].

At present, there is no clear understanding of projected future wave climate and resulting variations in longshore sediment transport rate along the Vietnam coast. Therefore, this study was undertaken with the specific aim of quantifying and analysing CC-driven variation in wave climate and potential sediment transport rates along the entire mainland coast of Vietnam for the future time spans 2041-2060 and 2081-2100 (relative to 1981-2000).

Using dynamically downscaled global circulation model (GCM)-derived wind fields and numerical wave modelling, here we derive the contemporary and future deep water wave climate from the Red River delta to the Mekong delta (Section 2), and propagate these waves to the nearshore zone. Using this wave information, we subsequently calculate the potential longshore sediment transport rates in different coastal stretches along the coast of Vietnam (Section 3).

\section{Offshore Wave Climate}

The Vietnam coast is connected to the Pacific Ocean through the South China Sea (referred to as the East Sea in Vietnam). Wave spectra in this region thus not only feature locally wind-generated waves, but also an important swell component.

In this part of the study, a MIKE21 SW model [12] (see Supplementary Materials for summary model description) is set up to derive contemporary (here: 1981-2000) and future offshore wave climates with bathymetry input from the General Bathymetric Chart of the Oceans (GEBCO) [13]. The model was first forced by a global hindcasted wind field (NCEP/CFSR, Saha et al., 2010) for the period 1981-2000, representing baseline contemporary (i.e., reference) conditions. The wind fields derived from the downscaled ECHAM5 [14] and The Geophysical Fluid Dynamics Laboratory Climate Model (GFDL CM2.1) [15] GCMs were then used to force the model for the period 1981-2000 and two future time spans: 2041-2060 and 2081-2100. A high-end future scenario of greenhouse gas emissions, A2 from the IPCC Special Report on Emission Scenarios (SRES), [16] was selected as the forcing scenario in the GCMs. This scenario describes a very heterogeneous world with high population growth, slow economic development and slow technological change, thus representing a situation close to the "worst-case" scenario that is more suited for risk-averse decision making.

ECHAM5 is the fifth-generation atmospheric general circulation model developed at the Max Planck Institute for Meteorology (MPIM). It uses $1.875^{\circ}$ longitude $\times 1.875^{\circ}$ latitude (T63) horizontal resolution with 31 layers in the atmospheric part of the model and $1.5^{\circ}$ longitude $\times 1.5^{\circ}$ latitude resolution with 40 layers in the oceanic model. Climate change simulations using ECHAM5 are carried out by adding observed atmospheric greenhouse gas and aerosol concentrations since the middle of the 19th century. The model simulations correspond to a mean global warming between $2.5^{\circ} \mathrm{C}$ and $4.1^{\circ} \mathrm{C}$ towards the end of this century, depending on how much greenhouse gas is emitted into the atmosphere [14].

GFDL CM 2.1 is based on a prior model version (GFDL CM 2.0, [17]) where significant changes were made to all parts of the model (atmosphere, land surface, ocean, and sea ice) with the aim of reducing errors and climate drift observed in the CM 2.0 model outcomes [15].

The downscaling Conformal Cubic Atmospheric Model (CCAM) [18] (see Supplementary Materials for summary model description) used in this study is developed and maintained at CSIRO 
Australia. The model features a conformal-cubic grid that is numerically appealing because of its quasi-uniformity, orthogonality and isotropy. All variables are located at the centre of the grid cells (please see Supplementary Materials for more model details). Here, CCAM was used to dynamically downscale ECHAM5 and GFDL CM 2.0 output in the study area. The monthly sea surface temperature (SST) biases have been corrected in the GFDL CM 2.1 GCM output to first order, and then the atmosphere has been rerun for consistency with the new SSTs. In the present study, the six hourly wind speeds ( $u$ and $v$ components) at $10 \mathrm{~m}$ elevation from ground were obtained from the CCAM. Wind data was extracted for three 20-year periods (1981-2000, 2041-2060 and 2081-2100) used for the analysis of contemporary and future climate scenarios.

In order to validate the GCM-derived wave fields, we forced the same spectral wave model (MIKE21 SW) with the NOAA National Centre for Environmental Prediction (NCEP) Climate Forecast System Reanalysis (CFSR) analytical global wind fields (hereon: reference model). The NCEP/CFSR dataset is a combination of atmosphere, ocean, sea ice hindcasts, and satellite data run in a coupled mode with a state-of-the-art data assimilation system [19]. NCEP/CFSR data was extracted at a spatial resolution of $0.5^{\circ} \times 0.5^{\circ}$ for six-hourly time steps of $u$ - and $v$-wind components at $10 \mathrm{~m}$ height at $600 \mathrm{~h}$, $1200 \mathrm{~h}, 1800 \mathrm{~h}, 0 \mathrm{~h}$ covering the "contemporary" period 1981-2000.

\subsection{Wave Model Calibration and Validation}

Wave data from ship observations and the European Centre for Medium-Range Weather Forecasts (ECMWF ERA-40) hindcast [20] were used to calibrate the reference South China Sea (or East Sea) spectral wave model forced with the NCEP/CFSR wind fields (Figure 1). Calibration was performed by systematically varying bottom friction, wave breaking and white-capping parameters.

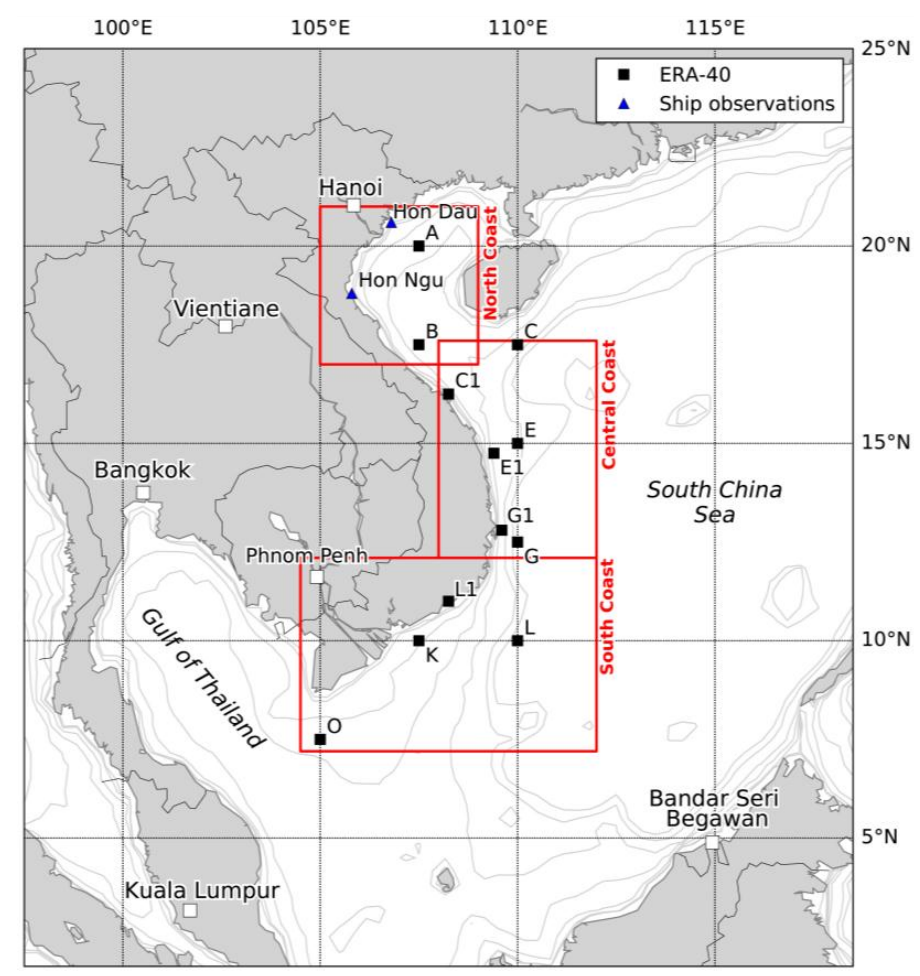

Figure 1. Locations of wave data used for model calibration. The extent of the figure corresponds to the wave model domain.

Table 1 shows a summary of the error statistics of the NCEP/CFSR-forced reference modelling results at two ship observation points (Hon Dau and Hon Ngu), and three ERA-40 wave locations (Points B, E and K, Figure 1). The time series comparison between the CFSR-forced model output 
and the ERA-40 data at station E is shown in Figure 2. Model validation at Hon Dau and Hon Ngu using ship observation data shows moderate model performance. Overall, the correlation coefficient $(r)$ values show good linear correlation of computed significant wave height and direction with the ship observation wave data. Model validation at Station B, E and K using ERA-40 wave data also shows good model performance with a small root mean square error (RMSE).

Table 1. Summary error statistics of modeling results at Hon Dau, Hon Ngu, Point B, E and K-Root Mean Squared Error (RMSE); Mean Absolute Error (MAE); Root Mean Square Error Mean (RMSEM); Root Mean Square Error over Standard Deviation (RMSES); $r$ (linear regression slope); $R^{2}$ (coefficient of determination).

\begin{tabular}{ccccccccccc}
\hline \multirow{2}{*}{ Index } & \multicolumn{2}{c}{ Hon Dau } & \multicolumn{2}{c}{ Hon Ngu } & \multicolumn{2}{c}{ Point B } & \multicolumn{2}{c}{ Point E } & \multicolumn{2}{c}{ Point K } \\
\cline { 2 - 11 } & $\boldsymbol{H} \boldsymbol{m 0}$ & $\boldsymbol{\theta} \boldsymbol{m}$ & $\mathbf{H} \boldsymbol{m 0}$ & $\boldsymbol{\theta} \boldsymbol{m}$ & $\boldsymbol{H} \boldsymbol{m 0}$ & $\boldsymbol{\theta} \boldsymbol{m}$ & $\boldsymbol{H} \boldsymbol{m} \mathbf{0}$ & $\boldsymbol{\theta} \boldsymbol{m}$ & $\boldsymbol{H} \boldsymbol{m} \mathbf{0}$ & $\boldsymbol{\theta} \boldsymbol{m}$ \\
\hline RMSE (m, deg) & 0.29 & 47.10 & 0.22 & 47.37 & 0.24 & 53.90 & 0.20 & 8.09 & 0.25 & 0.96 \\
MAE (m, deg) & 0.21 & 33.12 & 0.10 & 35.25 & 0.16 & 33.00 & 0.16 & 6.45 & 0.19 & 0.76 \\
RMSEM & 0.45 & 0.37 & 0.26 & 0.43 & 0.36 & 0.48 & 0.12 & 0.15 & 0.24 & 0.16 \\
RMSES & 1.11 & 0.82 & 0.55 & 0.74 & 0.81 & 1.03 & 0.33 & 0.66 & 0.39 & 0.60 \\
$r$ & 0.71 & 0.63 & 0.58 & 0.59 & 0.70 & 0.59 & 0.97 & 0.95 & 0.95 & 0.91 \\
$R^{2}$ & 0.43 & 0.22 & 0.43 & 0.45 & 0.49 & 0.47 & 0.94 & 0.90 & 0.90 & 0.71 \\
\hline
\end{tabular}
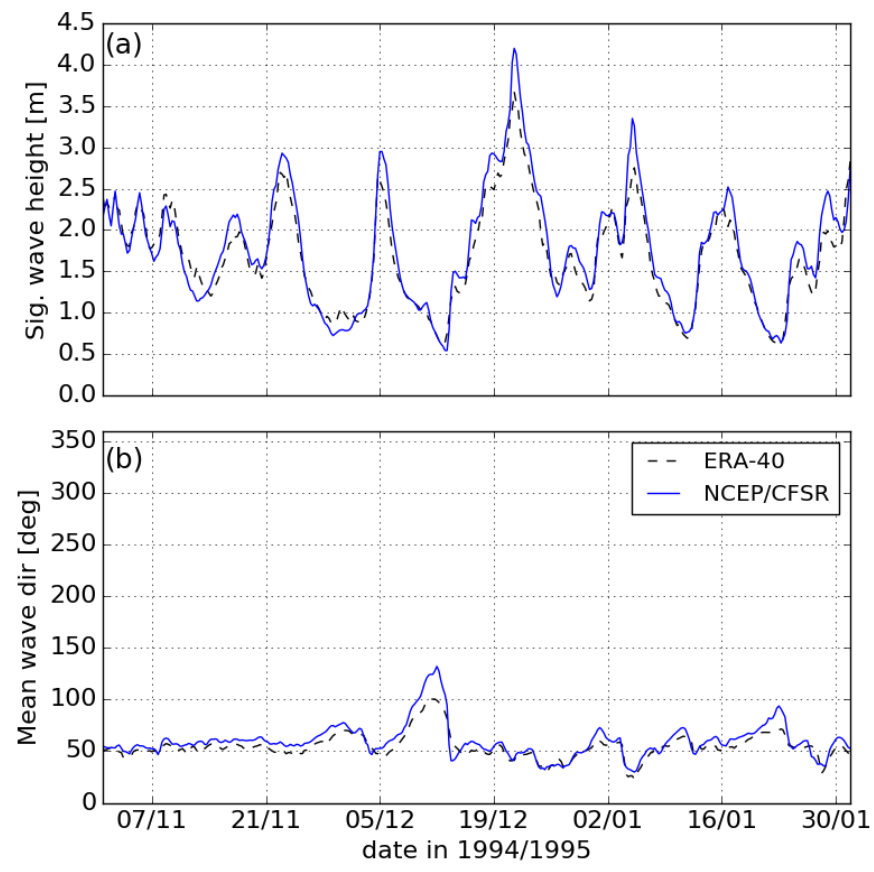

Figure 2. Comparison between wave characteristics from European Centre for Medium-Range Weather Forecasts (ECMWF ERA-40) and National Centre for Environmental Prediction Climate Forecast System Reanalysis (NCEP/CFSR)-forced model output at point E: (a) significant wave height; (b) mean wave direction.

Overall reference model performance gives moderate to good values of $r$ and $R^{2}$ for the comparison between computed values and ship observations/ERA- 40 wave characteristics. The best model performance is at Station $\mathrm{E}$ and the worst is at Hon Ngu. The reference model underestimates the higher values of the wave heights and shows a bias in the simulated direction for wave heights lower than $1.0 \mathrm{~m}$.

To gain confidence in the outcomes of the model runs forced by downscaled GCM wind fields for future time periods, we validated the wave model results forced by CCAM-downscaled GFDL CM2.1 
and ECHAM5 wind fields for the 1981-2000 period using the calibrated NCEP/CFSR time series via an inter-comparison of the monthly mean values of the significant wave height, peak period and mean wave direction (e.g., for point E, Figure 3). Overall, the differences in mean wave heights between the GCM outcomes and the reference run are small, except for the southern stations $\mathrm{K}$, L and O. Here, the GCM wind field-forced models underpredict the wave heights. As for the other two parameters, the GCM-forced models underpredict the wave period, and overpredict the wave direction in station Hon Ngu. In the other stations, the differences are negligible for the purposes of this study.
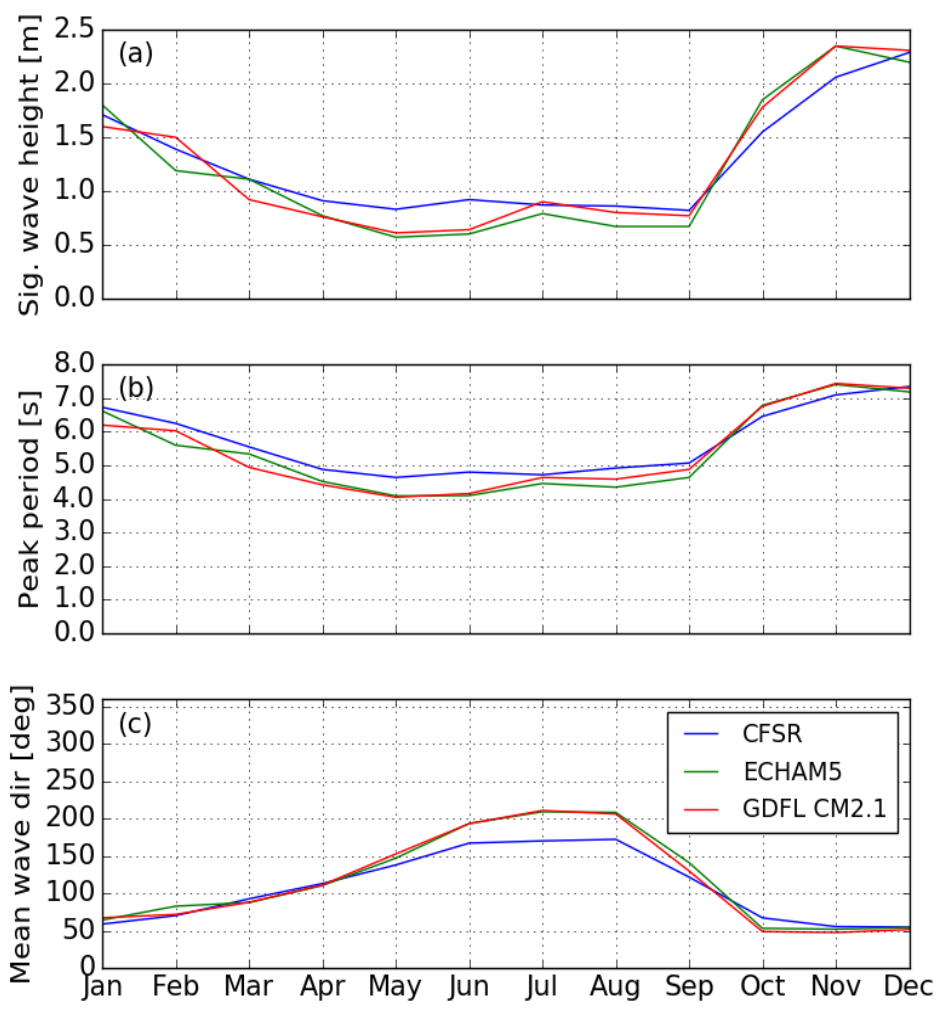

Figure 3. Validation of downscaled global circulation model (GCM) wind field-forced wave climate at point E, by comparison with the NCEP/CFSR model results for the period 1981-2000: (a) monthly mean significant wave height; (b) monthly mean peak period; (c) monthly mean wave direction.

\subsection{Modelling the Future Wave Climate}

The calibrated and validated spectral wave model was then forced by downscaled ECHAM5 and GFDL CM2.1 winds for the future time spans 2041-2060 and 2081-2100. Subsequently, the temporal changes were assessed for 14 locations along the Vietnam coast (Hon Dau, Hon Ngu, A, B, C, E, G, K, L and $\mathrm{O}$, and four additional nearshore wave locations C1, E1, G1 and L1 (Figure 1)). Again, we choose to compare the average (of the two GCMs) wave characteristics and look into the monthly variations.

As representative examples, we consider stations Hon Dau and G. The monthly mean wave climate at Hon Dau (Figure 4) in 2041-2060 shows a slight decrease of the mean significant wave height compared to the 1981-2000 reference period. It has a maximum change of $0.16 \mathrm{~m}(21 \%)$ in October and a minimum change of $0.04 \mathrm{~m}(7 \%)$ in April. The average monthly mean significant wave height in the timeframe 2081-2100 is less than the average mean significant wave height in 2040-2061. The monthly mean wave period is slightly increased by $0-0.28 \mathrm{~s}$ with a maximum difference of $0.28 \mathrm{~s}(5 \%)$ in November and a minimum difference of $0.02 \mathrm{~s}(0.4 \%)$ in February and October (in 2081-2100 relative to 1981-2000). The variation of the monthly mean wave direction is $0^{\circ}-15^{\circ}$. On average, the monthly mean wave direction turns clockwise throughout the year, with a maximum difference in clockwise direction by $15^{\circ}$ in September (in 2081-2100 relative to 1981-2000). At Station G, the monthly mean 
significant wave height varies between $0 \mathrm{~m}$ and $0.30 \mathrm{~m}$. The average mean significant wave height in 2041-2060 decreases throughout the year, relative to 1981-2000. On the other hand, in 2081-2100 (relative to 1981-2000), the average mean significant wave height is reduced during May to October by $0-0.10 \mathrm{~m}$ (less than $10 \%$ ) and significantly increased during November to January by $0.30 \mathrm{~m}(17 \%)$. The average of the monthly mean wave period has a similar trend as the average of the monthly mean significant wave height. The maximum difference is $0.43 \mathrm{~s}(9 \%)$ in September and November and the minimum difference is $0.02 \mathrm{~s}(0.5 \%)$ in March. The variation of the monthly mean wave direction lies between $0^{\circ}$ and $13^{\circ}$. In April and May, the monthly mean wave direction has slightly changed by $9^{\circ}$ in counter-clockwise direction and in September, the wave direction is shifted $13^{\circ}$ in clockwise direction (Figure 5).
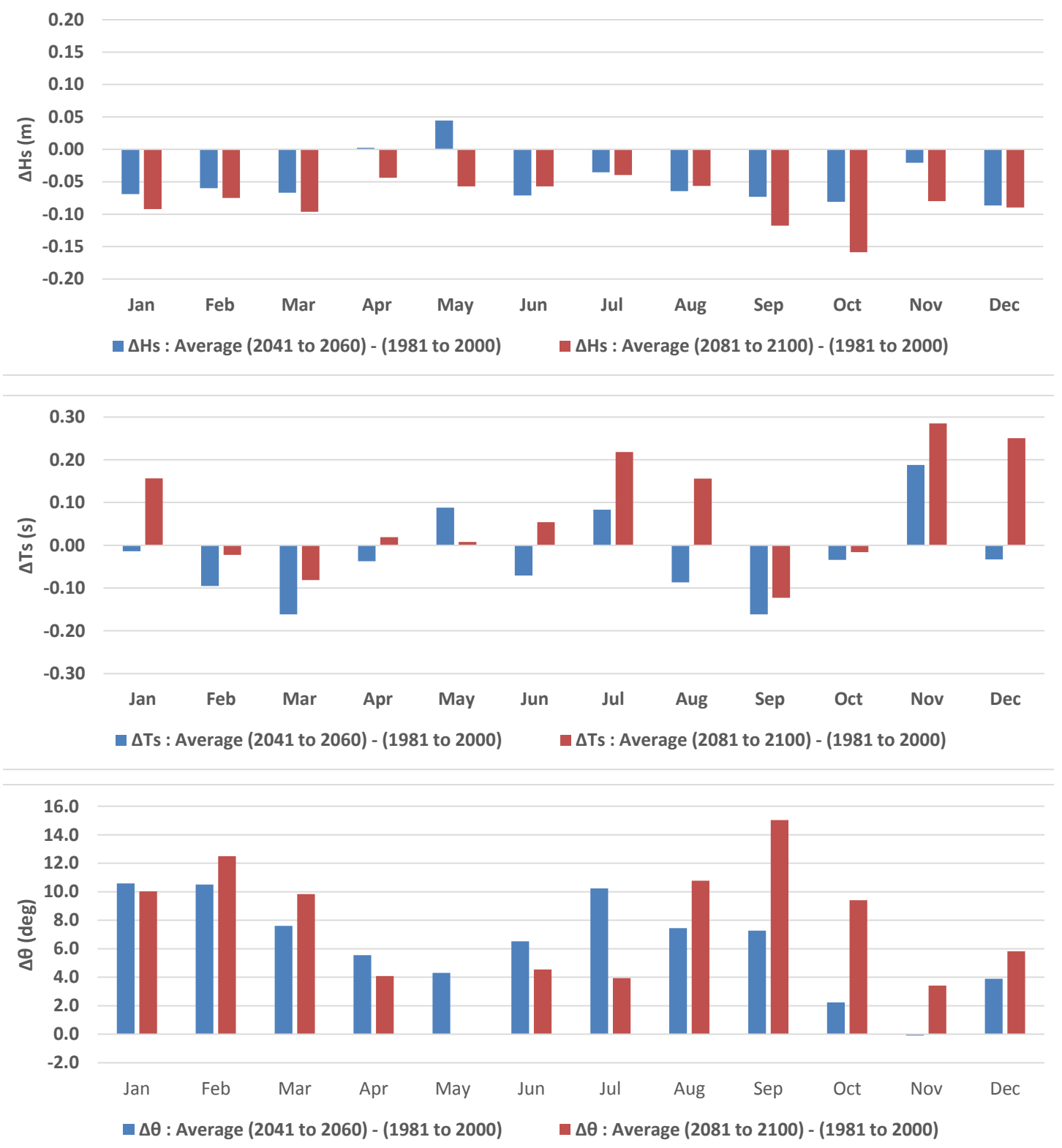

Figure 4. Changes in monthly mean wave height, direction and period at Hon Dau for periods 2041-2060 and 2081-2100 relative to the period 1981-2000. 


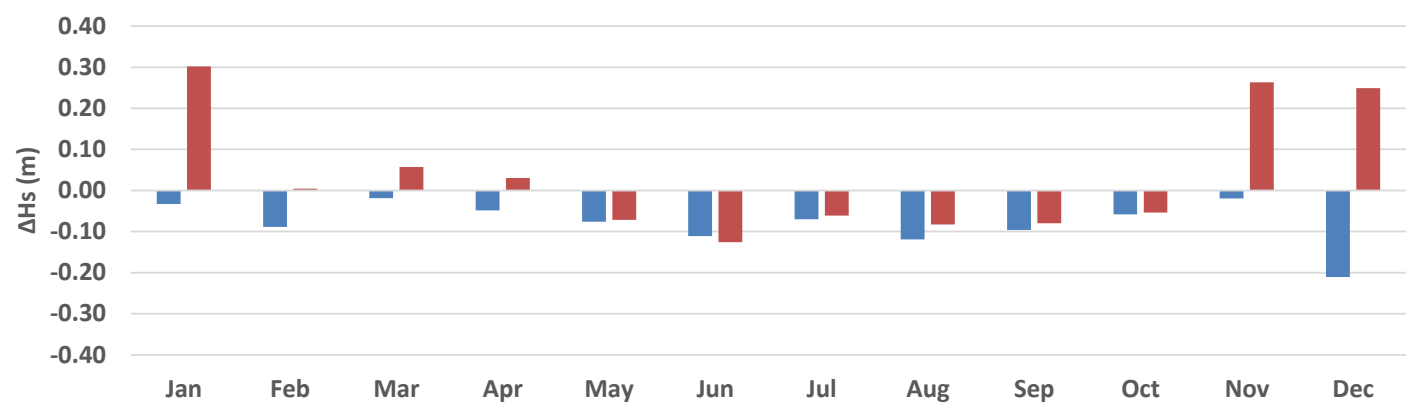

$\square \mathrm{Hs}$ : Average (2041 to 2060) - (1981 to 2000) $\quad \Delta \mathrm{Hs}$ : Average (2081 to 2100) - (1981 to 2000)

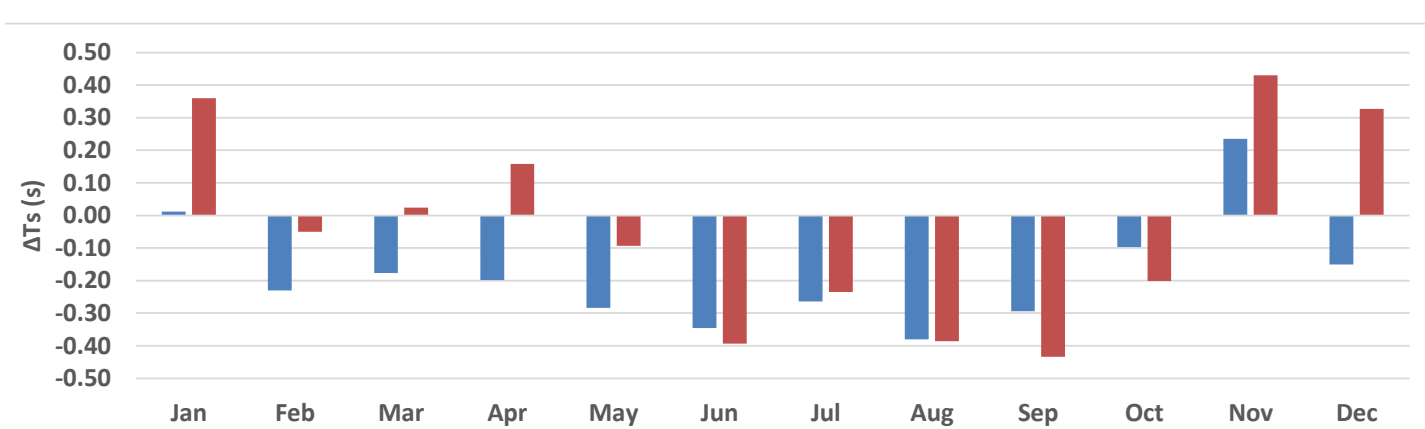

$\square \Delta$ Ts : Average (2041 to 2060) - (1981 to 2000) $\quad \Delta$ Ts : Average (2081 to 2100) - (1981 to 2000)

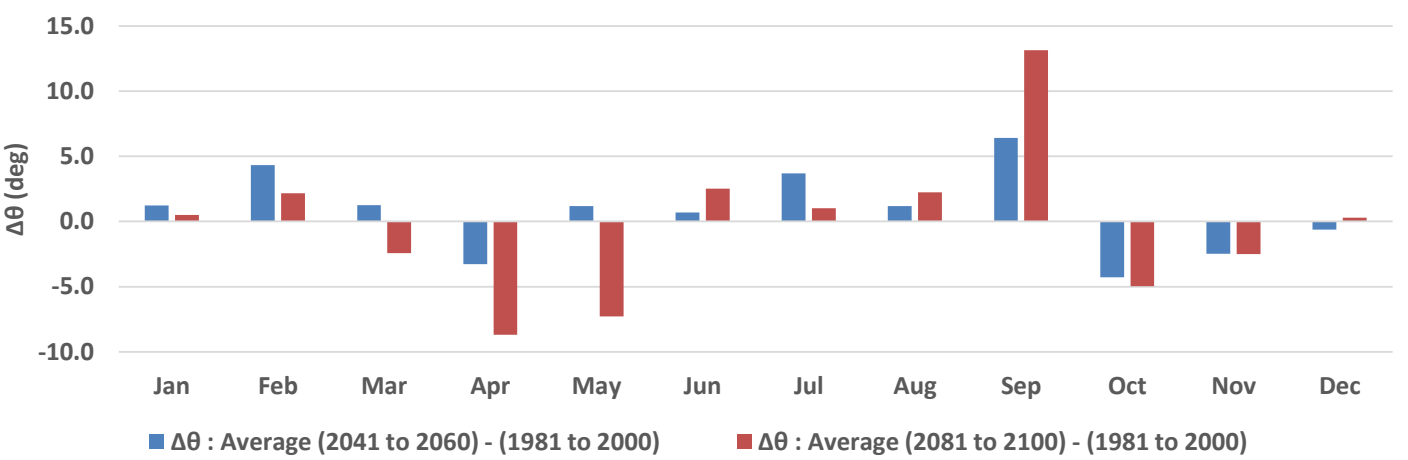

Figure 5. Changes in monthly mean wave height, direction and period at point $\mathrm{G}$ for periods 2041-2060 and 2081-2100 relative to the period 1981-2000.

Differences between the average contemporary and future wave climates (between 2041-2060 and 1981-2000, and between 2081-2100 and 1981-2000) are shown in Figure 6 for the 14 locations shown in Figure 1. Their spatial variability allows for a subdivision in three major areas: 1. northern coast (i.e., stations Hon Dau, Hon Ngu, A and B), 2. central coast (i.e., stations C, C1, E and E1), and 3. southern coast (i.e., stations G, G1, K, L, L1 and O) of Vietnam. 


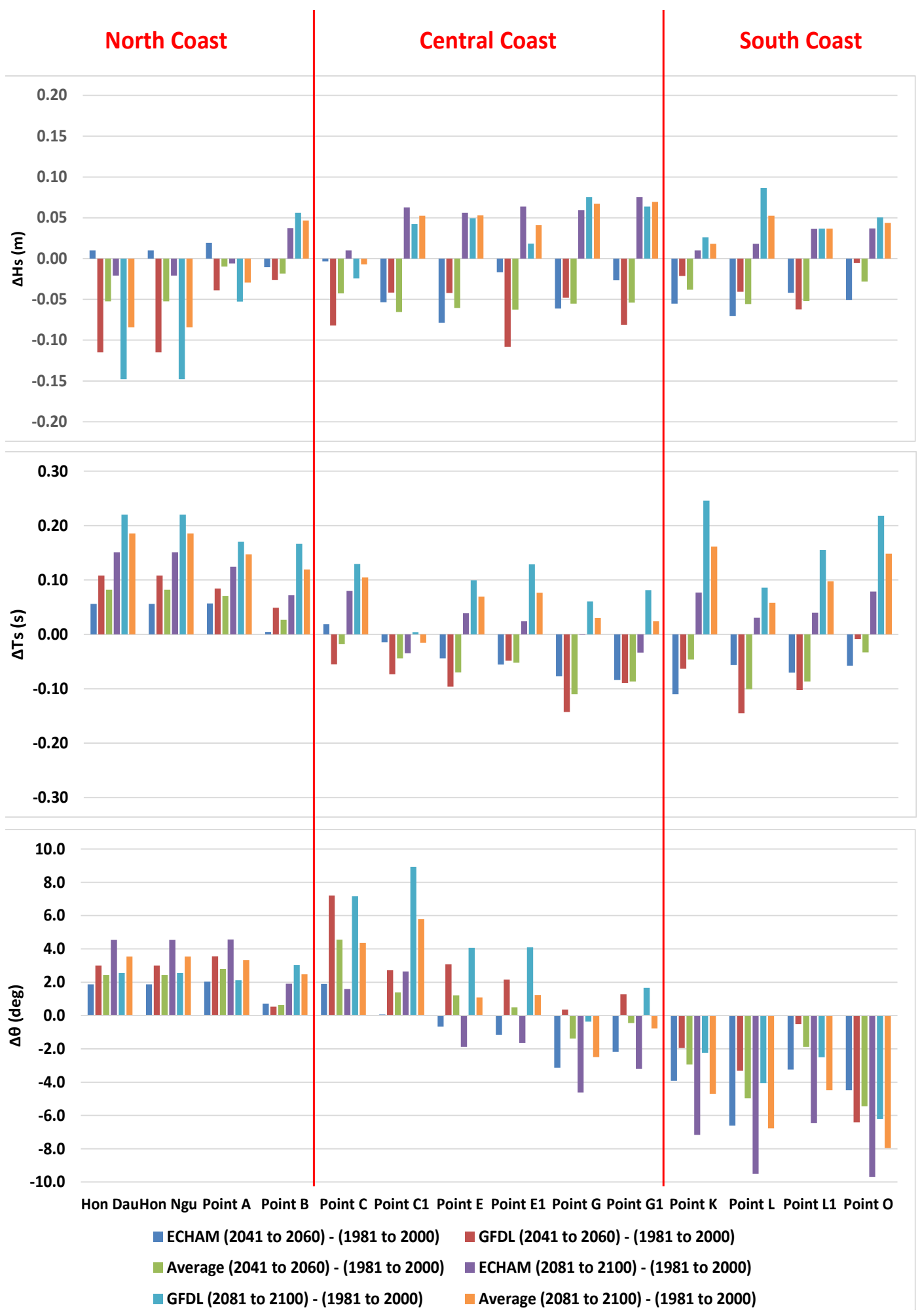

Figure 6. Changes in annual mean wave height, direction and period at all locations for periods 2041-2060 and 2081-2100 relative to 1981-2000 for simulations with inputs from different GCMs.

In northern Vietnam (stations Hon Dau, Hon Ngu, A and B), future significant wave heights slightly decrease along the coast by $1-5 \mathrm{~cm}(1 \%-7 \%)$ in $2041-2060$ and by $3-8 \mathrm{~cm}(3 \%-12 \%)$ in $2081-2100$. One exception is station $\mathrm{B}$, where we see an increase by $5 \mathrm{~cm}(4 \%)$. For changes of the future wave period distribution, the results show a slightly increasing trend at all stations by $0.03-0.08 \mathrm{~s}(1 \%-2 \%)$ in 
2041-2060 and $0.12-0.19 \mathrm{~s}(2 \%-4 \%)$ in 2081-2100. The future wave direction turns in the clockwise direction (towards the south) by $1^{\circ}-3^{\circ}(1 \%-2 \%)$ in $2041-2060$ and slightly more, by $3^{\circ}-4^{\circ}(2 \%-3 \%)$ in 2081-2100 from the mean southeasterly wave direction under contemporary conditions.

In central Vietnam (stations C, C1, E and E1), the future significant wave heights along the coast tend to decrease by around $4-6 \mathrm{~cm}(3 \%-7 \%)$ in the period $2041-2060$, and increase by $4-5 \mathrm{~cm}(1 \%-5 \%)$ in 2081-2100. The wave period at each station tends to decrease slightly by $0.02-0.07 \mathrm{~s}(1 \%)$ from 2041 to 2060 , and increase by $0.07-0.10 \mathrm{~s}(1 \%-2 \%)$ in $2081-2100$, except at station $\mathrm{C} 1$, where the average wave period reduces by $0.02 \mathrm{~s}$ by 2100 . The future wave direction turns in the clockwise direction (toward the south) by $1^{\circ}$ to $5^{\circ}(1 \%-4 \%)$ in the period $2041-2060$ and by $1^{\circ}$ to $6^{\circ}(1 \%-5 \%)$ in $2081-2100$ relative to 1981-2000.

In southernVietnam (stations G, G1, K, L, L1 and O), future monthly mean significant wave height decreases slightly by $3-6 \mathrm{~cm}(1 \%-8 \%)$ in $2041-2060$ and increases by $2-7 \mathrm{~cm}(1 \%-5 \%)$ in $2081-2100$. The future monthly mean wave period decreases slightly by $0.03-0.11 \mathrm{~s}(1 \%-2 \%)$ in the period 2041 to 2060 but, in contrast, increases by $0.02-0.16 \mathrm{~s}(1 \%-3 \%)$ in 2081-2100. The future monthly wave direction turns in the counter-clockwise direction (towards the north) by $2^{\circ}$ to $5^{\circ}(1 \%-4 \%)$ in $2041-2060$ and $3^{\circ}$ to $8^{\circ}(2 \%-6 \%)$ in $2081-2100$.

\subsection{Spatial Distribution of Changes in Wave Climate}

Time-averaged mean significant wave heights, wave periods and wave directions from downscaled GCM-derived wind fields for the contemporary period 1981-2000, projection periods 2041-2060 and 2081-2100, and their average long-term changes are used to represent spatial variations of future wave climate in Figures 6-9. Positive changes in wave direction indicate clockwise rotation (toward the south) and negative changes indicate counter-clockwise rotation (toward the north) of future wave directions. 

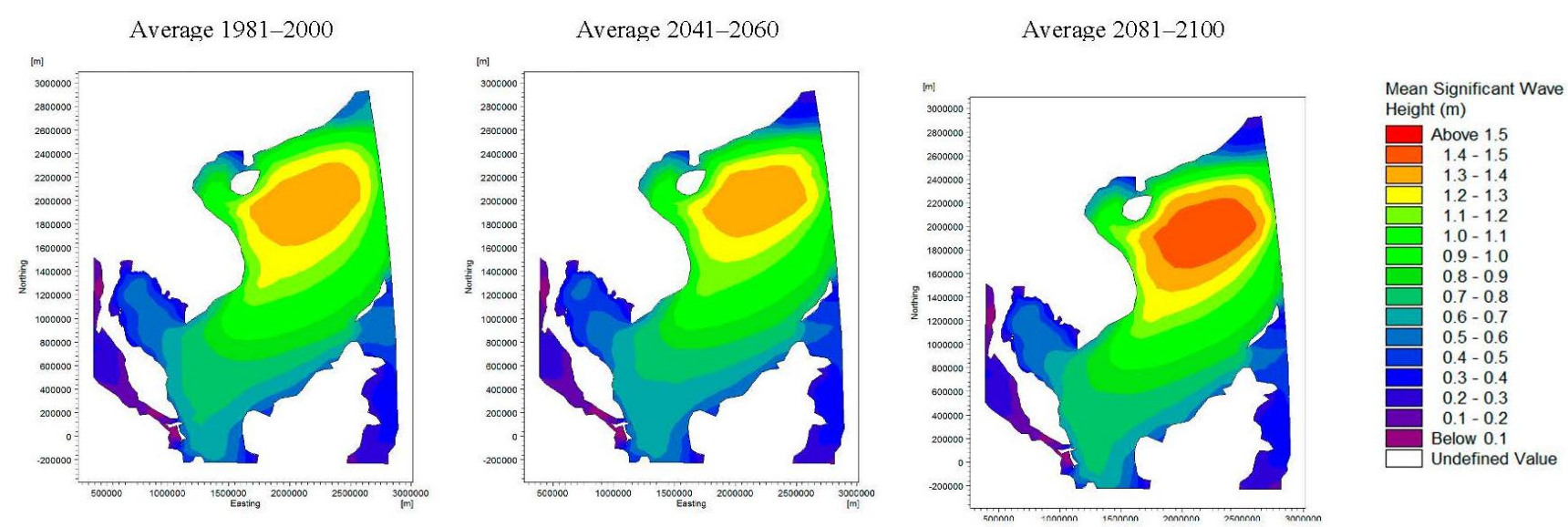

Difference of significant wave height between 2081-2100 and 1981-2000
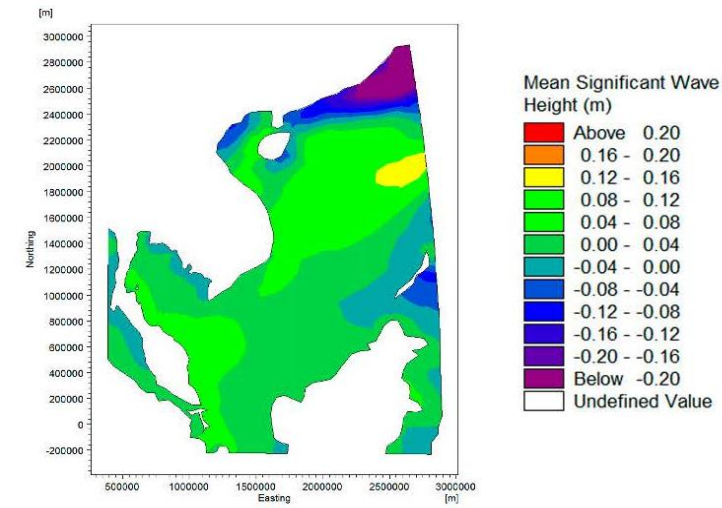

Figure 7. Spatial distribution of time-averaged ECHAM and GFDL mean significant wave height in 1981-2000, 2041-2060, 2081-2100 and the difference plot between 2081-2100 and 1981-2000. 

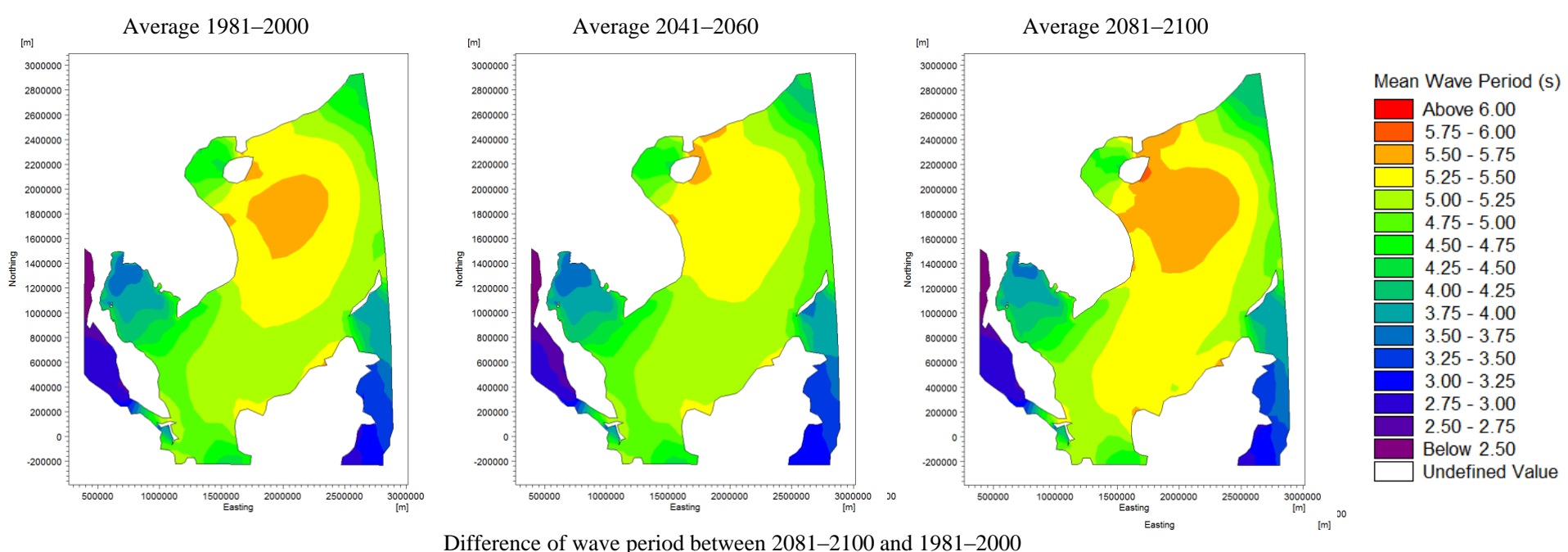

Difference of wave period between 2081-2100 and 1981-2000

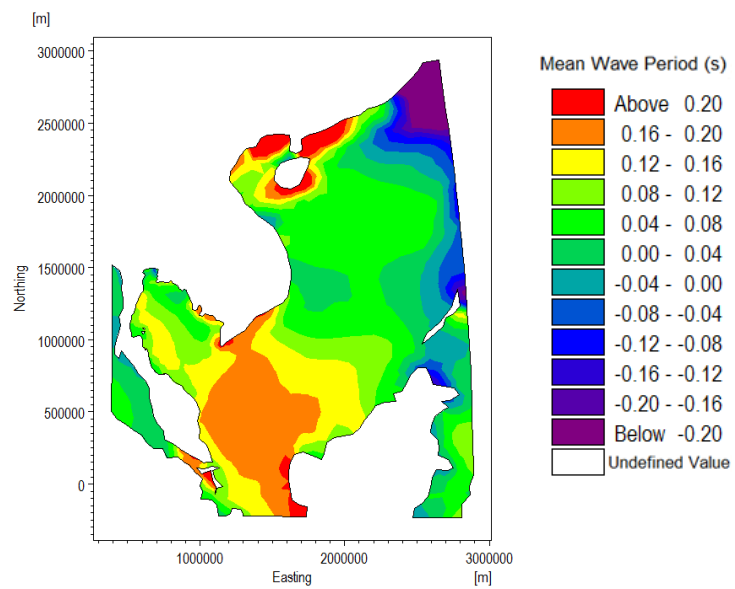

Figure 8. Spatial distribution of average ECHAM and GFDL mean wave period in 1981-2000, 2041-2060, 2081-2100 and the difference plot between 2081-2100 and 1981-2000. 

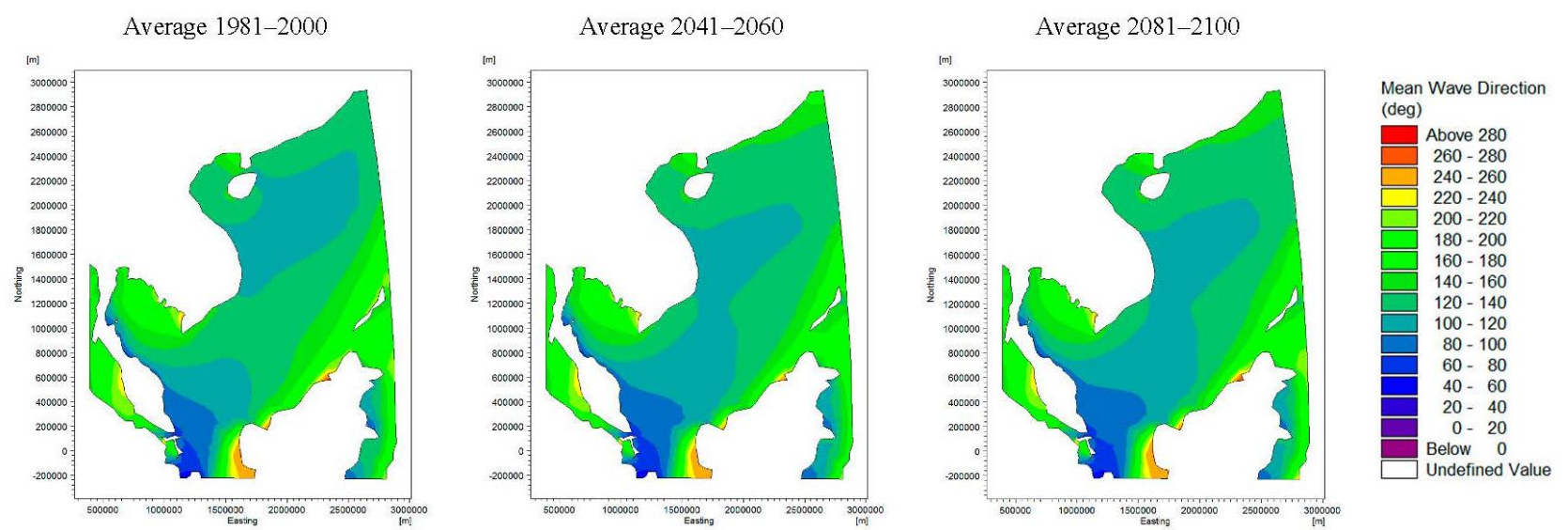

Difference of wave direction between 2081-2100 and 1981-2000
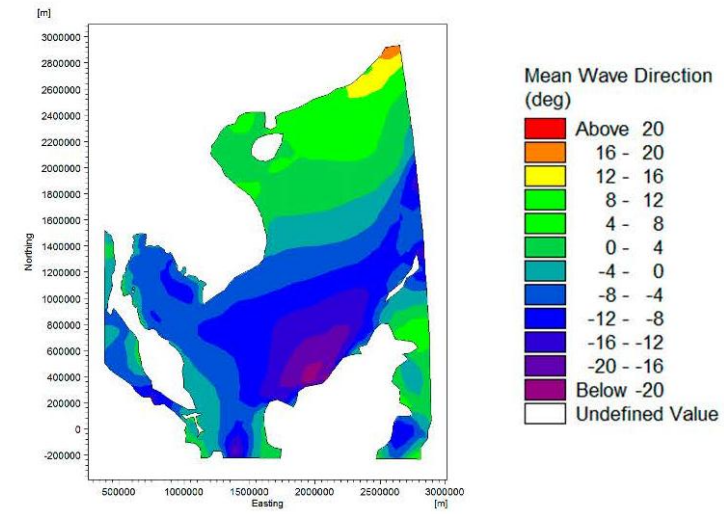

Figure 9. Spatial distribution of average ECHAM and GFDL mean wave direction in 1981-2000, 2041-2060, 2081-2100 and the difference plot between 2081-2100 and 1981-2000. 


\section{Potential Longshore Sediment Transport}

Next, we used the 1981-2000 and 2081-2100 offshore wave climate derived in Section 2 to determine the nearshore wave climate for both time spans for 22 different coastline sections along the coast of Vietnam (Figure 10). This was done by using the spectral wave model Simulating WAves Nearshore (SWAN) [21] (see Supplementary Materials for summary model description). The nearshore wave climate was subsequently used as the input to the GENEralized model for Simulating Shoreline Change (GENESIS) model [22] (see Supplementary Materials for summary model description) to estimate the annual average of potential longshore sediment transport (LST) at these 22 coastline sections.

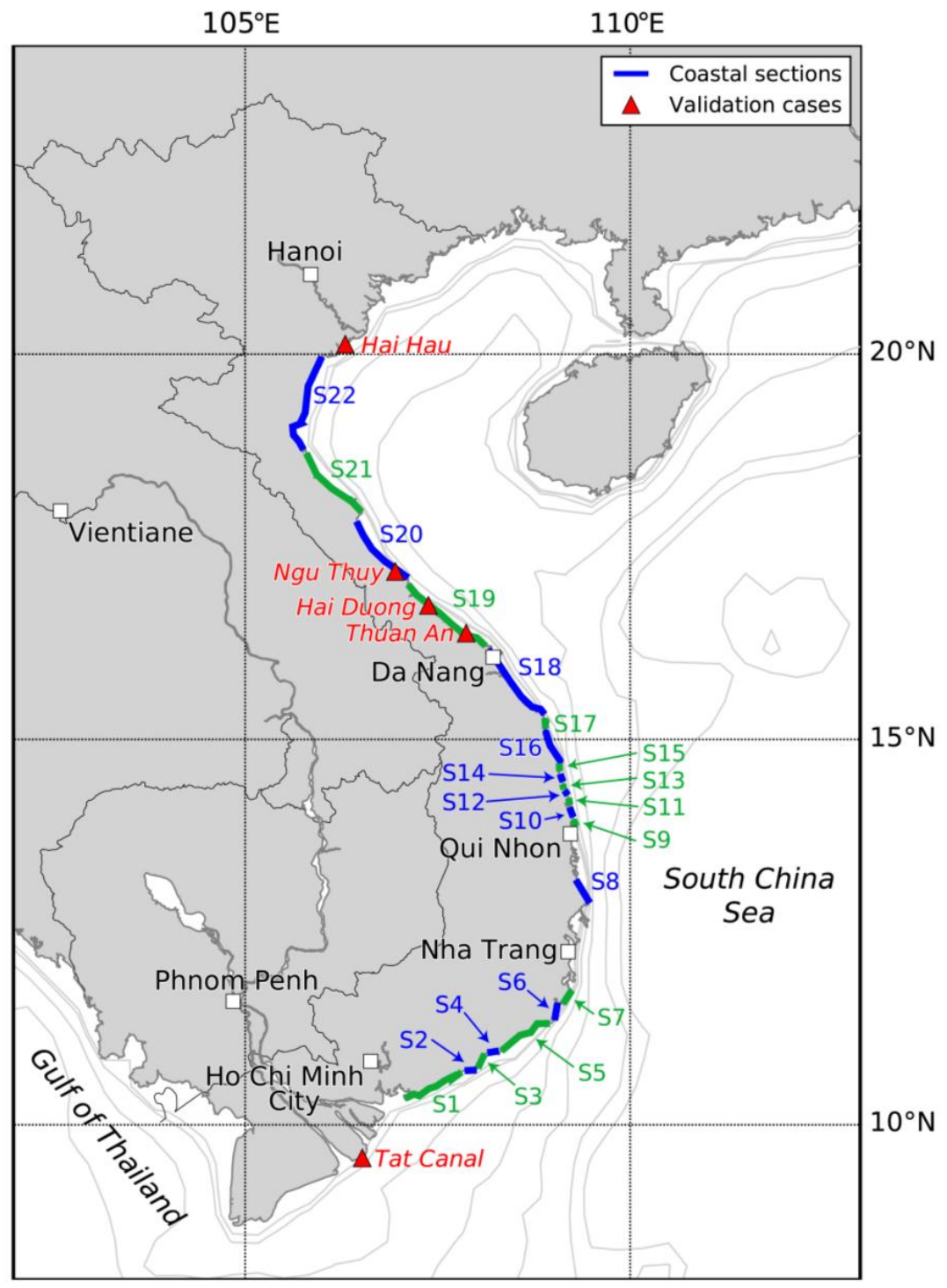

Figure 10. Locations of 22 selected coastal sections along the Vietnam coastline and model validation locations.

\subsection{Model Verification}

The GENESIS-estimated LST rates were compared with reported LST rates from literature. There are a number of studies of LST along the coast of Vietnam, but most of them focus on the central coast, especially at the coast of Thua Thien-Hue province. Estimations of LST rates at some areas along the 
coast of Vietnam from previous research studies (shown by red triangles in Figure 10) were selected for model verification. The results of these previous studies are summarized as follows:

(a) Northern coast of Vietnam at Hai Hau Beach (Nam Dinh province)

Hung and Dien [23] compute the LST at Hai Hau beach using the program SEDTRAN with input wave conditions for the period spanning 2001 and 2005. The estimated net sediment transport is $63,000 \mathrm{~m}^{3}$ /year in a southwesterly direction, while the gross transport is $490,000 \mathrm{~m}^{3}$ /year.

(b) Central coast of Vietnam at Thua Thien Hue province and Quang Binh province

Tien [24] calculated the LST in central Vietnam using the Bijker method, the CERC method and an improved method based on the Meyer-Peter Müller formula with a wave hindcast of 2002 . The computed results at Thuan An area (Thua Thien Hue province) were found to be in the range of $600,000-1,100,000 \mathrm{~m}^{3} /$ year for the total gross transport and 400,000-700,000 $\mathrm{m}^{3} /$ year for the net transport, which was directed to the northwest. The net transport at Hai Duong (Thua Thien Hue province) and Ngu Thuy (Quang Binh province) was about 1,500,000 $\mathrm{m}^{3} /$ year and 900,000 $\mathrm{m}^{3}$ /year respectively, both in the northwesterly direction.

Lam [25] evaluated different measurements and calculations of the LST for the coast of Thua Thien-Hue province reported by different authors throughout the period 1970-2004. The most reasonable results (which agreed with the observed development rate of sand spits and dredge records) were found to be in the range of $600,000-1,600,000 \mathrm{~m}^{3} /$ year for the gross transport and $300,000-700,000 \mathrm{~m}^{3} /$ year for the net transport, which is directed to the northwest.

(c) Southern coast of Vietnam at the Tat canal, in the Mekong delta

Doan et al. [26] calculated the LST at Tat canal (Phu Long province) using the LITDRIFT model with input wave conditions covering the period 1999 to 2008 . The estimated net sediment transport was found to be in the range of $150,000-170,000 \mathrm{~m}^{3} /$ year in a southwesterly direction.

The sediment transports in the period 1981-2000 at or near the above-mentioned verification locations, which are coastal Sections S1, S19, S20 and S22 (Figure 10), were computed by the GENESIS model. First, the calibration factors of GENESIS model $k_{1}$ and $k_{2}$ were set equal to the values of previous studies (refer to Supplementary Materials for description of these calibration factors), and gross and net transports were calculated for the selected coastal sections. Subsequently, the calibration factors were adjusted until the computed results of net and gross longshore sediment transport rates between this study and previous studies matched. The optimal values of the calibration parameters $k_{1}$ and $k_{2}$ thus obtained are shown in Table 2.

Table 2. Optimal calibration coefficients for GENESIS model.

\begin{tabular}{ccc}
\hline Coastal Section & $\boldsymbol{k}_{\mathbf{1}}$ & $\boldsymbol{k}_{\mathbf{2}}$ \\
\hline S1 & 0.95 & 0.50 \\
S19 & 0.65 & 0.50 \\
S20 & 0.75 & 0.50 \\
S22 & 0.80 & 0.40 \\
\hline
\end{tabular}

The computed results of net and gross LST rates from the GENESIS model at these coastal sections and corresponding values reported in literature are summarized in Tables 3 and 4 . 
Table 3. Comparison of computed and reported net longshore sediment transport rates at coastal Sections S1, S19, S20 and S22 (Positive transport direction is southward).

\begin{tabular}{ccccc}
\hline \multicolumn{2}{c}{ Study Area } & \multicolumn{3}{c}{ Estimates of $Q_{\text {net }}\left(\mathbf{m}^{3} /\right.$ Year) } \\
\hline \multirow{2}{*}{ Section } & Nearby Area & \multicolumn{2}{c}{ This Study } & \multirow{2}{*}{ Previous Study } \\
\cline { 3 - 4 } & & ECHAM Wave & GFDL Wave & \\
\hline S1 & Tat channel & 33,000 to 102,000 & 9000 to 77,000 & 150,000 to 170,000 \\
S19 & Thuan An beach & $-786,000$ to $-1,772,000$ & $-721,000$ to $-1,703,000$ & $-300,000$ to $-700,000$ \\
S19 & Hai Duong & $-786,000$ to $-1,772,000$ & $-721,000$ to $-1,703,000$ & $-1,500,000$ \\
S20 & Nqu Thuy & $-768,000$ to $-1,725,000$ & $-684,000$ to $-1,579,000$ & $-900,000$ \\
S22 & Hai Hau beach & $-21,000$ to 71,000 & 5000 to 111,000 & 63,000 \\
\hline
\end{tabular}

Table 4. Comparison of computed and reported gross longshore sediment transport rates at coastal Sections S1, S19, S20 and S22.

\begin{tabular}{ccccc}
\hline \multicolumn{2}{c}{ Study Area } & \multicolumn{3}{c}{ Estimates of $Q_{\text {gross }}\left(\mathbf{m}^{3} /\right.$ Year) } \\
\hline \multirow{2}{*}{ Section } & Nearby Area & \multicolumn{2}{c}{ This Study } & \multirow{2}{*}{ Previous Study } \\
\cline { 3 - 4 } & & ECHAM Wave & GFDL Wave & \\
\hline S1 & Tat channel & 96,380 to 168,000 & 73,892 to 151,000 & N/A \\
S19 & Thuan An beach & 787,000 to $1,772,000$ & 721,000 to $1,705,000$ & 600,000 to $1,600,000$ \\
S19 & Hai Duong & 787,000 to $1,772,000$ & 721,000 to $1,705,000$ & N/A \\
S20 & Nqu Thuy & 769,000 to $1,727,000$ & 686,000 to $1,580,000$ & N/A \\
S22 & Hai Hau beach & 77,000 to 136,000 & 53,000 to 152,000 & 490,000 \\
\hline
\end{tabular}

The computed results of LST rates vary annually and depend on the GCM used to force the wave model (ECHAM5 or GFDL CM2.1), as well as on the coastline orientation. Nevertheless, there is reasonable agreement between the computed results and the reported values. Differences in methods and periods of computation, accuracy of adopted coastline orientation, bathymetry and wave climate are the most likely reasons for the inconsistencies between previously reported LST rates and those computed in the present study.

\subsection{Modelling the Future Potential Sediment Transport}

Finally, GENESIS was applied with the above $k_{1}$ and $k_{2}$ values, with the wave climates obtained from forcing the spectral wave model with the ECHAM5 and GFDL CM2.1 wind fields to calculate annual LST at the 18 remaining coastal sections for 1981-2000 and 2081-2100 time spans.

The GENESIS results for the future period are compared with the potential sediment transport rate for the 1981-2000 wave climate. The results are summarized in Table 5.

Table 5. Changes in net longshore sediment transport due to climate change at 22 coastal sections along the Vietnam coastline (2081-2100 compared to 1981-2000).

\begin{tabular}{|c|c|c|c|}
\hline Region & Coastal Section & Change in Direction of Net LST & $\begin{array}{l}\text { Change in Magnitude of Net LST } \\
\text { Percentage and Order of Change }\end{array}$ \\
\hline \multirow{7}{*}{ South Coast } & S1 & No/Remains towards the south & $+62 \%\left(30,000 \mathrm{~m}^{3} /\right.$ year $)$ \\
\hline & S2 & $\begin{array}{l}\text { Yes/No dominant direction/change } \\
\text { towards the south }\end{array}$ & $-7 \%\left(1000 \mathrm{~m}^{3} /\right.$ year $)$ \\
\hline & S3 & No/Remains towards the south & $+34 \%\left(125,000 \mathrm{~m}^{3} /\right.$ year $)$ \\
\hline & S4 & $\begin{array}{l}\text { Yes/No dominant direction/change } \\
\text { towards the south }\end{array}$ & $-28 \%\left(2000 \mathrm{~m}^{3} /\right.$ year $)$ \\
\hline & S5 & No/Remains towards the south & $+50 \%\left(122,000 \mathrm{~m}^{3} /\right.$ year $)$ \\
\hline & S6 & No/Remains towards the south & $+37 \%\left(113,000 \mathrm{~m}^{3} /\right.$ year $)$ \\
\hline & S7 & No/Remains towards the south & $+40 \%\left(78,000 \mathrm{~m}^{3} /\right.$ year $)$ \\
\hline
\end{tabular}


Table 5. Cont.

\begin{tabular}{|c|c|c|c|}
\hline Region & Coastal Section & Change in Direction of Net LST & $\begin{array}{l}\text { Change in Magnitude of Net LST } \\
\text { Percentage and Order of Change }\end{array}$ \\
\hline \multirow{12}{*}{ Central Coast } & S8 & No/Remains towards the south & $-30 \%\left(145,000 \mathrm{~m}^{3} /\right.$ year $)$ \\
\hline & S9 & $\begin{array}{l}\text { Yes/No dominant direction/change } \\
\text { towards the north }\end{array}$ & $+240 \%\left(162,000 \mathrm{~m}^{3} /\right.$ year $)$ \\
\hline & S10 & No/Remains towards the south & $-7 \%\left(80,000 \mathrm{~m}^{3} /\right.$ year $)$ \\
\hline & S11 & No/Remains towards the south & $-22 \%\left(155,000 \mathrm{~m}^{3} /\right.$ year $)$ \\
\hline & S12 & No/Remains towards the south & $-30 \%\left(176,000 \mathrm{~m}^{3} /\right.$ year $)$ \\
\hline & S13 & No/Remains towards the south & $+16 \%\left(434,000 \mathrm{~m}^{3} /\right.$ year $)$ \\
\hline & S14 & No/Remains towards the south & $-23 \%\left(131,000 \mathrm{~m}^{3} /\right.$ year $)$ \\
\hline & S15 & No/Remains towards the south & $+9 \%\left(170,000 \mathrm{~m}^{3} /\right.$ year $)$ \\
\hline & S16 & No/Remains towards the south & $-15 \%\left(105,000 \mathrm{~m}^{3} /\right.$ year $)$ \\
\hline & S17 & No/Remains towards the south & $+23 \%\left(460,000 \mathrm{~m}^{3} /\right.$ year $)$ \\
\hline & S18 & No/Remains towards the north & $+45 \%\left(290,000 \mathrm{~m}^{3} /\right.$ year $)$ \\
\hline & S19 & No/Remains towards the north & $+10 \%\left(124,000 \mathrm{~m}^{3} /\right.$ year $)$ \\
\hline \multirow{3}{*}{ North Coast } & S20 & No/Remains towards the north & $+15 \%\left(170,000 \mathrm{~m}^{3} /\right.$ year $)$ \\
\hline & $\mathrm{S} 21$ & No/Remains towards the north & $+20 \%\left(113,000 \mathrm{~m}^{3} /\right.$ year $)$ \\
\hline & S22 & $\begin{array}{l}\text { Yes/No dominant direction/change } \\
\text { towards the north }\end{array}$ & $+60 \%\left(5000 \mathrm{~m}^{3} /\right.$ year $)$ \\
\hline
\end{tabular}

\section{Discussion}

Only a few wave-downscaling studies have been undertaken at similar spatial scales as the present study (i.e., $\sim 1000 \mathrm{~km}$ ). While the greenhouse gas emission scenarios, GCMs, RCMs, wave models and spatial resolutions therein differ among the studies (and the present study), all of them indicate changes in mean significant wave heights (by 2100, relative to the end of the 20th century) between $0.1 \mathrm{~m}-0.5 \mathrm{~m}$ (Table 6), which is somewhat larger than those projected for the same period for Vietnam in this study. The studies at the Bay of Biscay [27] and New South Wales, Australia [28] also indicate a rotation of up to $5^{\circ}$ in mean wave direction for the same period, which is consistent with the projected variations in mean wave direction obtained for the Vietnam coast in the present study.

Table 6. Summary of previous regional scale wave-downscaling studies.

\begin{tabular}{cccc}
\hline Study Area & Wave Model Resolution & $\begin{array}{c}\text { Projected Variation in Mean Wave } \\
\text { Conditions by 2100 (Relative to End } \\
\text { of 20th Century) }\end{array}$ & Source \\
\hline Western North Pacific & $\sim 100 \mathrm{~km}$ & Hs decrease/increase by $<0.5 \mathrm{~m}$ & {$[29]$} \\
United Kingdom & $\sim 12 \mathrm{~km}$ & Hs slight increase $/$ decrease $<0.5 \mathrm{~m}$ & {$[30]$} \\
North Sea & $\sim 5.5 \mathrm{~km}$ & Hs slight increase $/$ decrease $<0.2 \mathrm{~m}$ & {$[31]$} \\
US West Coast & $\sim 25 \mathrm{~km}$ & Hs decrease by $<0.5 \mathrm{~m}$ & {$[32]$} \\
NW Mediterranean Sea & $\sim 50 \mathrm{~km}$ & Hs decrease $/$ increase by $<0.1 \mathrm{~m}$ & {$[33]$} \\
New South Wales, Australia & $\sim 10 \mathrm{~km}$ & Hs decrease $<0.1 \mathrm{~m}$ and rotation of $5^{\circ}$ & {$[28]$} \\
Bay of Biscay & $\sim 10 \mathrm{~km}$ & Hs decrease $<10 \%$ and rotation of $5^{\circ}$ & {$[27]$} \\
\hline
\end{tabular}

The very few reported studies of potential climate change-driven variations in LST have been done at much smaller spatial scales than the present study $(\sim 2000 \mathrm{~km})$. Furthermore, the methods adopted in these studies are highly variable, ranging from assumed future wave conditions and simple analytical LST equations to downscaled wave conditions and physics-based empirical LST formulations. Nevertheless, summary details of such reported studies are shown in Table 7, indicating that climate change-driven variations in LST can indeed be significant, which is broadly consistent with the findings of the present study. 
Table 7. Summary of previous studies investigating climate change-driven variations in longshore sediment transport rates.

\begin{tabular}{ccll}
\hline Study Area & $\begin{array}{c}\text { Length and Time Scale } \\
\text { of Study }\end{array}$ & \multicolumn{1}{c}{ Projected Future Variations in LST } & Source \\
\hline NW Portugal & $35 \mathrm{~km} ; 25$ years. & $\begin{array}{l}\text { CC-driven variations in wave conditions could } \\
\text { result in a shoreline retreat rate double or triple } \\
\text { that due to SLR }\end{array}$ & {$[34]$} \\
\hline Po River Delta, Italy & $100 \mathrm{~km} ; 100$ years. & $\begin{array}{l}\text { CC-driven variations in wave conditions could } \\
\text { lead to 10\%-20\% decrease in LST }\end{array}$ \\
\hline Catalan coast, Spain & $300 \mathrm{~km} ; 50$ years. & $\begin{array}{l}\text { CC-driven variations in wave conditions could } \\
\text { lead to 50\%-100\% decrease in LST rates, and at } \\
\text { some locations changes in net LST directions }\end{array}$ & [36] \\
\hline
\end{tabular}

\section{Conclusions}

This study has quantified climate change-driven variations in mean wave characteristics and resulting variations in potential longshore sediment transport rate along the $\sim 2000 \mathrm{~km}$ mainland coast of Vietnam using dynamically downscaled wind fields derived from two global climate models, two spectral wave models (MIKE21 SW and SWAN), and a longshore sediment transport model (GENESIS). Results show that the 2081-2100 averaged significant wave height along the northern coast of Vietnam could be up to $8 \mathrm{~cm}$ lower (compared to 1981-2000), have slightly longer wave periods (increase of $0.20 \mathrm{~s}$ ), and shift towards the south (clockwise) by up to $4^{\circ}$. Along the central coast, the 2081-2100 averaged significant wave height is projected to slightly increase by $5 \mathrm{~cm}$ (relative to 1981-2000), with an average wave period increase of up to $0.08 \mathrm{~s}$ and a directional shift to the south (clockwise) up to $6^{\circ}$. For the same time period, averaged significant wave height is projected to slightly increase by $7 \mathrm{~cm}$, combined with a longer wave period (increase of $0.16 \mathrm{~s}$ ) and a shift towards the north (counter-clockwise) by up to $8^{\circ}$ along the southern coast of Vietnam. The most significant future potential change in the mean wave climate along the Vietnamese coastline is therefore the projected change in wave directions, leading to a zone of wave direction divergence in the vicinity of Da Nang.

The computed results indicate that the volume and direction of longshore sediment transport along the coast of Vietnam is rather variable. For 1981-2000 conditions, the annual averages from ECHAM5 and GFDL CM2.1-forced models at 22 contiguous coastal sections were found to be in the range of $11,000-2,748,000 \mathrm{~m}^{3}$ /year for the total gross transport. Net longshore sediment transport estimates ranged between $1400-1,426,000 \mathrm{~m}^{3}$ /year in a northerly direction in coastal Sections S2, S4 and S18-S21. In Sections S1, S3, S5-S17 and S22, the net transport ranged between 35,000-2,740,000 m³ /year in a southerly direction. For the future time span 2081-2100, the annual average results along the 22 coastal sections are in the range of $10,000-3,403,000 \mathrm{~m}^{3} /$ year for the total gross transport. The net longshore transport ranges between $2000-1,569,000 \mathrm{~m}^{3}$ /year in a northerly direction at coastal Sections S4, S9, S18-S21. In coastal Sections S1-S3, S5-S8, S10-S17 and S22 the net sediment transport is estimated at $500-3,174,000 \mathrm{~m}^{3}$ /year in a southerly direction.

The above projections indicate that climate change (CC)-induced future variations in longshore sediment transport rates are very substantial along the coast of Vietnam, with up to 0.5 million $\mathrm{m}^{3}$ /year increase in the net transport rate at some locations. Such large changes in net longshore sediment transport rates can have major implications on the position and orientation of some sections of the Vietnamese coastline, emphasizing the urgent need for detailed coastal morphological studies and quantitative risk assessments at vulnerable coastal areas along the coast of Vietnam. This appears to be particularly the case in the vicinity of the highly developed Da Nang city (coastal Sections S17-S19) due to the large projected future change in longshore sediment transport direction and magnitude therein, with potentially an additional $875,000 \mathrm{~m}^{3}$ of sand being transported away from the area per year by the turn of the 21st century. 
Supplementary Materials: The following are available online at www.mdpi.com/2077-1312/4/4/86/s1. Description of Models: CCAM, MIKE21, SWAN, GENESIS.

Acknowledgments: The authors wish to thank Mark Hemer (CSIRO, Australia) for providing valuable information pertaining to wave-downscaling studies done elsewhere. A.D. and J.R. were supported by the Dutch Ministry of Infrastructure and Environment (I \& M). R.R. was supported by the AXA Research Fund, and the Deltares Strategic Research Programme "Bouwen aan de Kust".

Author Contributions: A.D. wrote the paper and undertook all SWAN model simulations. R.R. and A.D. initiated the project and conceptualized the idea. R.R. and J.R. contributed substantially to writing the paper and analysis of model outcomes. S.T. and S.W. carried out Mike 21 and GENESIS simulations. M.T. provided the CCAM model description and carried out the CCAM downscaling.

Conflicts of Interest: The authors declare no conflict of interest.

\section{References}

1. Nicholls, R.J.; Wong, P.P.; Burkett, V.R.; Codignotto, J.O.; Hay, J.E.; McLean, R.F.; Ragoonaden, S.; Woodroffe, C.D. Coastal systems and low-lying areas. In Climate Change 2007: Impacts, Adaptation and Vulnerability; Contribution of Working Group II to the Fourth Assessment Report of the Intergovernmental Panel on Climate Change; Cambridge University Press: Cambridge, UK, 2007.

2. Wong, P.P.; Losada, I.J.; Gattuso, J.P.; Hinkel, J.; Khattabi, A.; McInnes, K.L.; Saito, Y.; Sallenger, A. Coastal systems and low-lying areas. In Climate Change 2014: Impacts, Adaptation, and Vulnerability. Part A: Global and Sectoral Aspects; Contribution of Working Group II to the Fifth Assessment Report of the Intergovernmental Panel on Climate Change; Field, C.B., Barros, V.R., Dokken, D.J., Mach, K.J., Mastrandrea, M.D., Bilir, T.E., Chatterjee, M., Ebi, K.L., Estrada, Y.O., Genova, R.C., et al., Eds.; Cambridge University Press: Cambridge, UK; New York, NY, USA, 2014; pp. 361-409.

3. Wassmann, R.; Hien, N.X.; Hoanh, C.T.; Tuong, T.P. Sea level rise affecting the Vietnamese Mekong Delta: Water elevation in the flood season and implications for rice production. Clim. Chang. 2004, 66, 89-107. [CrossRef]

4. Bergillos, R.J.; López-Ruiz, A.; Ortega-Sánchez, M.; Masselink, G.; Losada, M.A. Implications of delta retreat on wave propagation and longshore sediment transport-Guadalfeo case study (southern Spain). J. Mar. Geol. 2016, 382, 1-16. [CrossRef]

5. Cowell, P.J.; Stive, M.J.; Niedoroda, A.W.; Swift, D.J.; de Vriend, H.J.; Buijsman, M.C.; Nicholls, R.J.; Roy, P.S.; Kaminsky, G.M.; Cleveringa, J.; et al. The Coastal-Tract (Part 2): Applications of Aggregated Modelling to Lower-order Coastal Change. J. Coast. Res. 2003, 19, 828-848.

6. Cowell, P.J.; Stive, M.J.; Niedoroda, A.W.; de Vriend, H.J.; Swift, D.J.; Kaminsky, G.M.; Capobianco, M. The Coastal-Tract (Part 1): A Conceptual Approach to Aggregated Modelling of Low-order Coastal Change. J. Coast. Res. 2003, 19, 812-827.

7. Pranzini, E. Updrift river mouth migration on cuspate deltas: Two examples from the coast of Tuscany (Italy). Geomorphology 2001, 38, 125-132. [CrossRef]

8. Ranasinghe, R. Assessing climate change impacts on open sandy coasts: A review. Earth Sci. Rev. 2016, 160, 320-332. [CrossRef]

9. Duong, T.M.; Ranasinghe, R.; Walstra, D.; Roelvink, D. Assessing climate change impacts on the stability of small tidal inlet systems: Why and How? Earth Sci. Rev. 2016, 154, 369-380. [CrossRef]

10. FitzGerald, D.M.; Fenster, M.S.; Argow, B.A.; Buynevich, I.V. Coastal impacts due to sea-level rise. Annu. Rev. Earth Planet. Sci. 2008, 36, 601-647. [CrossRef]

11. Dissanayake, D.M.; Ranasinghe, R.W.; Roelvink, J.A. The morphological response of large tidal inlet/basin systems to relative sea level rise. Clim. Chang. 2012, 113, 253-276. [CrossRef]

12. Sorensen, O.R.; Kofoed-Hansen, H.; Rugbjerg, M.; Sorensen, L.S. A Third-Generation Spectral Wave Model Using an Unstructured Finite Volume Technique. In Proceedings of the 29th International Coastal Engineering Conference, Lisbon, Portugal, 19-24 September 2004.

13. British Oceanographic Data Centre (BODC). The GEBCO Digital Atlas published by the British Oceanographic Data Centre on behalf of IOC and IHO. Available online: http:/ / www.gebco.net (accessed on 12 December 2016). 
14. Roeckner, E.; Bäuml, G.; Bonaventura, L.; Brokopf, R.; Esch, M.; Giorgetta, M.; Hagemann, S.; Kirchner, I.; Kornblueh, L.; Manzini, E.; et al. The Atmospheric General Circulation Model ECHAM 5. PART I: Model Description; MPI-Report No. 349; Max-Planck-Institut für Meteorologie: Hamburg, Germany, 2003; p. 127.

15. Delworth, T.L.; Broccoli, A.J.; Rosati, A.; Stouffer, R.J.; Balaji, V.; Beesley, J.A.; Cooke, W.F.; Dixon, K.W.; Dunne, J.; Dunne, K.A.; et al. GFDL's CM2 global coupled climate models. Part I: Formulation and simulation characteristics. J. Clim. 2006, 19, 643-674. [CrossRef]

16. Nakićenović, N.; Alcamo, J.; Davis, G.; de Vries, B.; Fenhann, J.; Gaffin, S.; Gregory, K.; Grübler, A.; Jung, T.Y.; Kram, T. IPCC Special Report on Emissions Scenarios (SRES); Working Group III, Intergovernmental Panel on Climate Change (IPCC); Cambridge University Press: Cambridge, UK, 2000; p. 570.

17. Anderson, J.L.; Balaji, V.; Broccoli, A.J.; Cooke, W.F. The new GFDL global atmosphere and land model AM2 LM2: Evaluation with prescribed SST simulations. J. Clim. 2004, 17, 4641-4673.

18. McGregor, J.L. C-CAM: Geometric Aspects and Dynamical Formulation; CSIRO Marine and Atmospheric Research Technical Report 70; CSIRO: Melbourne, Australia, 2005.

19. Saha, S.; Moorthi, S.; Pan, H.L.; Wu, X.; Wang, J.; Nadiga, S.; Tripp, P.; Kistler, R.; Woollen, J.; Behringer, D.; et al. The NCEP climate forecast system reanalysis. Bull. Am. Meteorol. Soc. 2010, 91, 1015-1057. [CrossRef]

20. Uppala, S.M.; KÅllberg, P.W.; Simmons, A.J.; Andrae, U.; Bechtold, V.D.C.; Fiorino, M.; Gibson, J.K.; Haseler, J.; Hernandez, A.; Kelly, G.A.; et al. The ERA-40 re-analysis. Q. J. Meteorol. Soc. 2005, 131, 2961-3012. [CrossRef]

21. Booij, N.; Ris, R.C.; Holthuijsen, L.H. A third-generation wave model for coastal regions: 1. Model description and validation. J. Geophys. Res. Oceans 1999, 104, 7649-7666. [CrossRef]

22. Hanson, H.; Kraus, N.C. GENESIS: Generalized Model for Simulating Shoreline Change; Report 1. Technical Reference (No. CERC-TR-89-19-1); Coastal Engineering Research Center: Vicksburg, MS, USA, 1989.

23. Hung, N.M.; Dien, D.C. Effects of the Storm Number 7 (DAMREY) on the Sea Dyke System of Nam Dinh Province; Technical report; Centre for Marine Environment Survey, Research and Consultation (CMESRC), Institute of Mechanics: Hanoi, Vietnam, 2006.

24. Tien, T.Q. Use of hindcast wave field by WAM model for calculation of sediment transport in littoral zone of Vietnam Central. In Proceedings of the 14th OMISAR Workshop on Ocean Models, Taipei, Taiwan, 26-29 October 2004.

25. Lam, N.T. Hydrodynamics and Morphodynamics of a Seasonally Force Tidal Inlet System. Ph.D. Thesis, Delft University of Technology, Delft, The Netherlands, 22 June 2009.

26. Doan, Q.T.; Chen, Y.C.; Quach, T.T.; Mishra, P.K. Numerical modeling in shore line evolution prediction: Case study of Tat Dike, Vietnam. Int. J. Earth Sci. Eng. 2013, 6, 1251-1259.

27. Charles, E.; Idier, D.; Thiébot, J.; le Cozannet, G.; Pedreros, R.; Ardhuin, F.; Planton, S. Present wave climate in the Bay of Biscay: Spatiotemporal variability and trends from 1958 to 2001. J. Clim. 2012, 25, 2020-2039. [CrossRef]

28. Hemer, M.A.; McInnes, K.L.; Ranasinghe, R. Climate and variability bias adjustment of climate model-derived winds for a southeast Australian dynamical wave model. Ocean Dyn. 2012, 62, 87-104. [CrossRef]

29. Shimura, T.; Mori, T.N.; Hemer, M.A. Variability and future decreases in winter wave heights in the Western North Pacific. Geophys. Res. Lett. 2016, 43, 2716-2722. [CrossRef]

30. Wolf, J.; Lowe, J.; Howard, T. Climate Downscaling: Local Mean Sea-Level, Surge and Wave Modelling. Chapter 2. In Broad Scale Coastal Simulation: New Techniques to Understand and Manage Shorelines in the Third Millennium; Nicholls, R.J., Dawson, R.J., Day, S.A., Eds.; Springer: Amsterdam, The Netherlands, 2014; pp. 79-102.

31. Grabemann, I.; Groll, N.; Möller, J.; Weisse, R. Climate change impact on North Sea wave conditions: A consistent analysis of ten projections. Ocean Dyn. 2015, 65, 255-267. [CrossRef]

32. Erikson, L.H.; Hegermiller, C.A.; Barnard, P.L.; Ruggiero, P.; van Ormondt, M. Projected wave conditions in the Eastern North Pacific under the influence of two CMIP5 climate scenarios. Ocean Model. 2015, 96, 171-185. [CrossRef]

33. Casas-Prat, M.; Sierra, J.P. Projected future wave climate in the NW Mediterranean Sea. J. Geophys. Res. Oceans 2013, 118, 3548-3568. [CrossRef]

34. Coelho, C.; Silva, R.; Veloso-Gomes, F.; Taveira-Pinto, F. Potential effects of climate change on northwest Portuguese coastal zones. ICES J. Mar. Sci. 2009, 66, 1497-1507. [CrossRef] 
35. Bonaldo, D.; Benetazzo, A.; Sclavo, M.; Carniel, S. Modelling wave-driven sediment transport in a changing climate: A case study for northern Adriatic Sea (Italy). Reg. Environ. Chang. 2015, 15, 45-55. [CrossRef]

36. Casas-Prat, M.; Sierra, J.P. Trend analysis of wave direction and associated impacts on the Catalan coast. Clim. Chang. 2012, 115, 667-691. [CrossRef]

(c) 2016 by the authors; licensee MDPI, Basel, Switzerland. This article is an open access article distributed under the terms and conditions of the Creative Commons Attribution (CC-BY) license (http://creativecommons.org/licenses/by/4.0/). 